\title{
DISTRIBUTION OF FECAL INDICATOR BACTERIA IN SEDIMENT OF LOCAL OPEN CHANNELS RECEIVING JOHKASOU EFFLUENT
}

\author{
Joni Aldilla Fajri' ${ }^{1)}$, Toshiro Yamada ${ }^{2)}$, Ahmad S. Setiyawan ${ }^{3)}$, Fusheng Li $^{4)}$ \\ ${ }^{1)}$ Faculty of Civil Engineering and Planning, University of Islam Indonesia, Kaliurang Km 14,5, Yogyakarta, 55584, \\ Indonesia \\ ${ }^{2)}$ Faculty of Engineering, Gifu University, Yanagido 1-1, 501-1193, Japan \\ ${ }^{3}$ Department of Environmental Engineering, Bandung Institute of Technology, Ganesha 10, Bandung, 40132, Indonesia \\ ${ }^{4)}$ River Basin Research Center, Gifu University, Yanagido 1-1, 501-1193, Japan \\ E-mail :joni.af@uii.ac.id
}

\begin{abstract}
Onsite wastewater treatment system named Johkasou has been widely applied in the Japanese rural areas, which the effluent is mainly discharged into stream channels. However, Johkasou effluent would potentially be a source of contamination that can deteriorate water and sediment quality of the receiving downstream network. In order to identify the effect of Johkasou effluent particularly in sediment, a study on the distribution of fecal indicators (F-RNA bacteriophages, total coliform (TC), and Escherichia coli [E. coli]) in several sediment spots of local open channels receiving Johkasou effluent was conducted. The results showed that the contents of F-RNA bacteriophages, TC and E. coli in the sediment of open channels were detected in high levels while those contents in the sediment of Johkasou drainage channel were up to two orders magnitude higher than in the open channel. A high number of fecal bacteria in the receiving open channels was majorly influenced by the number of domestic households. Moderate correlations of fecal bacteria indicator with solid sediment and volatile sediment indicate that the sediment particles can be carriers of microbes to the downstream water networks. Therefore, water flushing and hydraulic events are suggested to reduce sediment depth that contained fecal bacteria indicator in the open channel.
\end{abstract}

Keywords: Distribution, fecal indicator bacteria, Johkasou, Sediment

\section{INTRODUCTION}

Onsite domestic systems have been stated as a potential source of fecal pollution in the water environment (Ahmed et al., 1995, Griffin et al., 2003). The inappropriate performance of onsite domestic systems releases the nutrients, organic matter, fecal indicators, and pathogens through effluents into the natural water bodies (Brontowiyono et al., 2013; Withers et al., 2011). After discharged into natural stream waters, treated effluents contained fecal indicators may suspend in the overlying water and/or settled down onto the sediment by associated with settleable-particles. So, it can increase the microbial number in the water and sediment especially fecal contaminants, e.g., total coliform and Escherichia coli. The high number of fecal indicators in the environment can be linked to the presence of a waterborne pathogen that has a significant impact on human health risk.

Besides effluents of onsite domestic systems, living organisms including fecal indicators in sediment bed can be an alternative source of microbial contaminants in th decentralized environment. Sediment has been identified as a reservoir for E. coli based on the comparisons of bacterial concentration in sediment with a concentration in the water column directly above the 
sediment layer. Many studies reported that sediments contain a higher population of both fecal coliform and E. coli than the overlying water and their long survival in the sediment (Davies et al., 1995; Rahman and Soupir., 2009). The survival of fecal indicators in sediment depends on the availability of several factors, such as soluble organic matter and nutrient (Jamieson et al., 2005a,b), protection from the predators (Jamieson et al., 2005a,b), and shielding from exposure to UV sunlight (Koirala et al., 2008).

The continuous effluents discharged from onsite domestic treatment systems would potentially be a primary source of fecal contamination in the water environment (Jamieson et al., 2003). Previous studies reported that high concentrations of total coliform and E. coli were recorded in both water and sediment of channels receiving effluents from Johkasou, an advanced onsite domestic system in Japan (Setiyawan et al., 2014). That high concentration of fecal indicators was still observed although during high flow condition which indicates less hydrological influenced on the fecal indicator in rural areas (Jamieson et al., 2003). The microbes associated sediment particles have an important role in transporting and resuspension of microbial indicators through the settleable-particles (Jamieson et al., 2004; Characklis et al, 2005). Thus, high level of fecal indicators in sediment can contaminate the downstream water network by their disposition with settleable particles during growing seasons such as heavy rainfall and storm runoff.

Several studies had documented the distribution and transport of microbes in sewage systems of urban areas (Kapoor et al. 2015; Ashley et al. 2015) and in big natural water such as rivers and estuaries (Panasiuk et al. 2015; Sowah et al. 2014). Little is known, however, about the distribution of fecal indicators in the sediment of stream channels of decentralized areas which its effluents are constantly discharged. Stream channels of decentralized areas have different characteristics compared to natural rivers since the channels are artificially made of concrete material and low flow condition due to the main inputs from decentralized systems and underground water. Therefore, the objective of this study was to evaluate the distribution and survival of microbial indicators in sediment open channels of the local water environment receiving Johkasou effluents. To achieve this goal, the assessments of microbial indicators (heterotrophic bacteria, total coliform, and E. coli) in several sediment spots along open channels were performed and their affinities with sediment particles were also measured.

\section{METHODOLOGY}

\subsection{Site description}

The study site is located in Gifu, Japan, near a residential area with a population around 250 
inhabitants (Fig. 1). A total 52 household uses Johkasou facility in this area 39 houses (75\%) using Gappei Johkasou and 13 households (25\%) using Tandoku Johkasou. Sediment and water samples were collected from seven sampling site (St) along 1-m-wide open channels surrounding the residential area (St.1 - St.7). A sampling site in the channel of Johkasou effluents (St. JO) was collected, which the effluents from 16 Gappei Johkasou facilities were consistently discharged into the open channel before St.6. Along open channels, other water inputs were also recognized from the effluent of 10 Tandoku Johkasou and 2 Gappei Johkasou before St.2; effluents of 21 Gappei Johkasou facilities and underground water between St.3 and St.4; and a paddy field area runoff during the agricultural period from May to August.

\subsection{Sediment characterization}

Samples collection. Samples of water and sediments were collected in three times during fine weather in winter (January $28^{\text {th }}, 2013$ ) and spring (June $11^{\text {th }}, 2014$ ), and end of autumn (Dec $9^{\text {th }}$, 2014) at several points along 200-m open channels that received effluents from Johkasou facilities. Sediments were also collected at Johkasou drainage channel and agricultural soils surrounding the open channels. The sediment mixed water were collected using a tube with an inner diameter of 30 $\mathrm{cm}$ for St.1 to St.7; a small tube with an inner diameter of $10 \mathrm{~cm}$ for site in the Johkasou drainage channel (St.JO); The mixed liquor from each site was then collected by placing the sampling tube on the sediment bed, mixing the sediment with the overlying water, and collecting mixed sediment with overlying water in the tube. The sediment sample was then placed in a new 250-ml polypropylene bottle and was then placed into a cooler box prior transported to the laboratory. Sediment samples were stored at $5{ }^{\circ} \mathrm{C}$ and analyzed on the day of collection. 


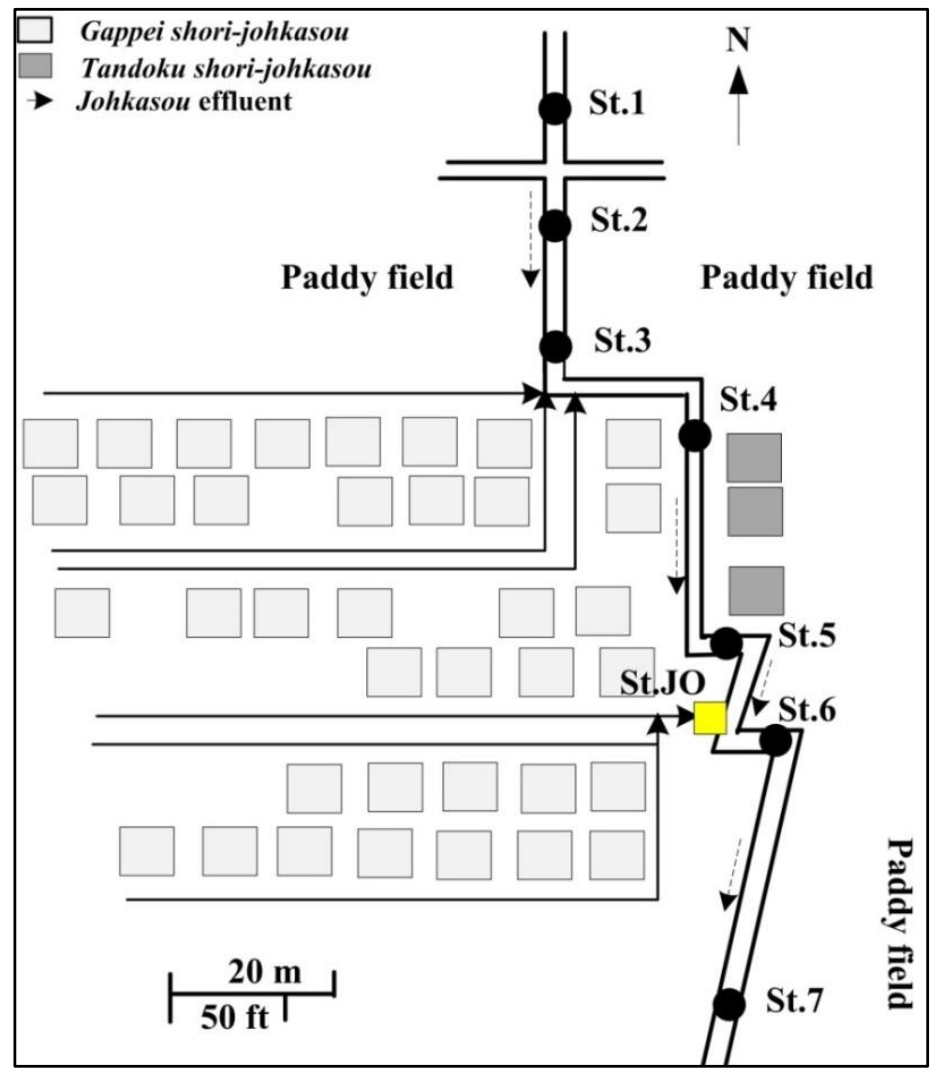

Figure 1 Distribution of sediment sites along open channel receiving Johkasou effluents in a residential area.

Particle size analysis. Particle size distributions of sediment were classified using sieving method referred to the standard of The Japanese Geotechnical Society (JGS 0051-2000) with size scales as follow; silt/clay $<63 \mu \mathrm{m}$; fine sand $63-250 \mu \mathrm{m}$; medium sand $250-850 \mu \mathrm{m} ; 850 \mu \mathrm{m}-2 \mathrm{~mm}$ coarse sand. The sediment samples from St. 4, JO, and 7 were selected as a representative of sediment fraction sample from difference channel, which was collected on December 9, 2014. Briefly, $250 \mathrm{~mL}$ mixture of sediment and water was placed on a set sieving scale as explained above. The samples were stirred on each of sieve and the residue through the sieve washed using the deionized water until the wash water runs clear. Prior dry weight analysis, the residue was then placed on a large evaporation dish by carefully back-wash the sieve.

Dry weight determination. A known weight of residues was placed in an oven at $105{ }^{\circ} \mathrm{C}$ for $24 \mathrm{~h}$ and the proportion of each gravel, sand, and mud were measured. Then, dry residues were further used to determine the dry volatile organic content by placed in an oven at $600{ }^{\circ} \mathrm{C}$ for $30 \mathrm{~min}$. The percent dry weight was then calculated by difference from these results. 


\subsection{Microbial enumeration}

Sediment extraction. Approximately $1 \mathrm{~g}$ well-mixed wet sediment was placed in $15 \mathrm{ml}$ centrifuge tube and centrifuged at $2,500 \times \mathrm{g}, 15^{\circ} \mathrm{C}$ for $10 \mathrm{~min}$ to separate between remaining water and sediment. The bulk wet-sediment was then divided into two groups; one portion for measuring fecal bacteria indicator and another for F-phages. For fecal bacteria analysis, the centrifuged sediment was mixed by adding $50 \mathrm{ml}$ deionized sterile PBS water for $30 \mathrm{~min}$ and then centrifuged at 4,000 $\times \mathrm{g}$, $15^{\circ} \mathrm{C}$ for $15 \mathrm{~min}$ (Davies et al., 1995). The supernatant was then subjected to further fecal bacteria analyses listed below. For measuring F-phages in sediment samples, viral particles were first extracted using 3\% beef extract (Kyokuto Pharmaceutical Industry Co., Ltd, Tokyo, Japan) at pH 9 and centrifuged at $12,000 \times \mathrm{g}$ for $10 \mathrm{~min}$, and then the supernatant was used for further analysis.

Microbiological analysis. The HPC bacteria, TC, and E. coli in sediment and water samples were enumerated based on the standards method (APHA, 2005). The HPC bacteria were determined by the plate count method using tryptone glucose yeast extract (TGYE) agar. Fecal indicator bacteria such as TC and E. coli were conducted by the multiple tubes fermentation technique using colicatch reagents (ES Colicatch 1000, Eiken Chemical, Japan) within a series of 10-fold dilution, with three tubes each dilution. And, the F-phages were analyzed based on the Indah et al. (2011).

\subsection{Statistical analysis}

Principal Component Analysis (PCA) was used to identify a better interpretation from water and sediment quality. PCA analysis was conducted to all data from all sampling site exclude St. JO using Microsoft Office Excel 2010 and IBM ${ }^{\circledR}$ SPSS Statistic version 21.

\section{RESULTS AND DISCUSSION}

\subsection{Sediment Characteristics}

Classifications of particles size in the sediment of upstream and downstream of open channel and Johkasou drainage channel were summarized in Table 1. The particle size distributions were relatively different between channels. Medium sand particles were the large fraction in the open channel and Johkasou drainage channel. At St. 4, the medium fraction was around 40.7\% among the total sediment, while at St. 7 , it was $28.5 \%$ of the total sediment weight. Sediment particles at St. JO were categorized as the almost same percentage for each fraction excluding silt/clay $(21.3 \%$ coarse sand, $23.3 \%$ medium sand, and $31.3 \%$ fine sand). The proportion of mud seemed increased from upstream to the downstream channel. This indicates the transfer of settleable particles to 
downstream, which might also transport the associated microbial indicator.

The each fraction of particles size was then extracted to measure the contents of HPC, TC and $E$. coli (Fig. 2). High contents of TC were found at fraction of silt/clay for most of the sites whereas the $E$. coli contents were detected high at fraction of clay/silt for all sites as well although there is no significant difference in the fraction of particles size for E. coli. The contents of HPC bacteria were observed at all of particles size fractions with the high content found at fractions of medium sand and silt/clay. The high contents of microbial indicators at fraction of silt/clay for most of the sites may indicate that the microbial indicators can associate with very light sediment that easy to be resuspended and transported into downstream areas. The high content of volatile sediment in silt/clay may introduce as the organic sources that important for bacteria growth.

Table 1. Classification of sediment particles in sediments using wet sieving method

\begin{tabular}{lcccc}
\hline & $\begin{array}{c}\text { Coarse } \\
\text { sand }^{\mathrm{a}}\end{array}$ & $\begin{array}{c}\text { Medium } \\
\text { sand }^{\mathrm{b}}\end{array}$ & Fine sand $^{\mathrm{c}}$ & silt/clay $^{\mathrm{d}}$ \\
\hline St. 4 & & & & \\
Fraction (\%) & 7.5 & 40.7 & 29.8 & 10.5 \\
Organic content $(\%)$ & 7.0 & 6.2 & 5.2 & 4.4 \\
Particle density $\left(\mathrm{g} / \mathrm{cm}^{3}\right)$ & 0.006 & 0.012 & 0.010 & 0.015 \\
St. JO & & & & \\
Fraction $(\%)$ & 21.3 & 23.3 & 31.3 & 2 \\
Organic content $(\%)$ & 4 & 4.7 & 9.2 & 7.3 \\
Particle density $\left(\mathrm{g} / \mathrm{cm}^{3}\right)$ & 0.006 & 0.015 & 0.002 & 0.005 \\
St. 7 & & & & \\
Fraction $(\%)$ & 19.2 & 28.5 & 12.7 & 13.3 \\
Organic content $(\%)$ & 9.5 & 8.3 & 7.5 & 5 \\
Particle density $\left(\mathrm{g} / \mathrm{cm}^{3}\right)$ & 0.003 & 0.010 & 0.009 & 0.009 \\
\hline a =2 mm - $850 \mu \mathrm{m}, \mathrm{b}=850-250 \mu \mathrm{m}, \mathrm{c}=250-63 \mu \mathrm{m}, \mathrm{d}=63 \mu \mathrm{m}<$ &
\end{tabular}



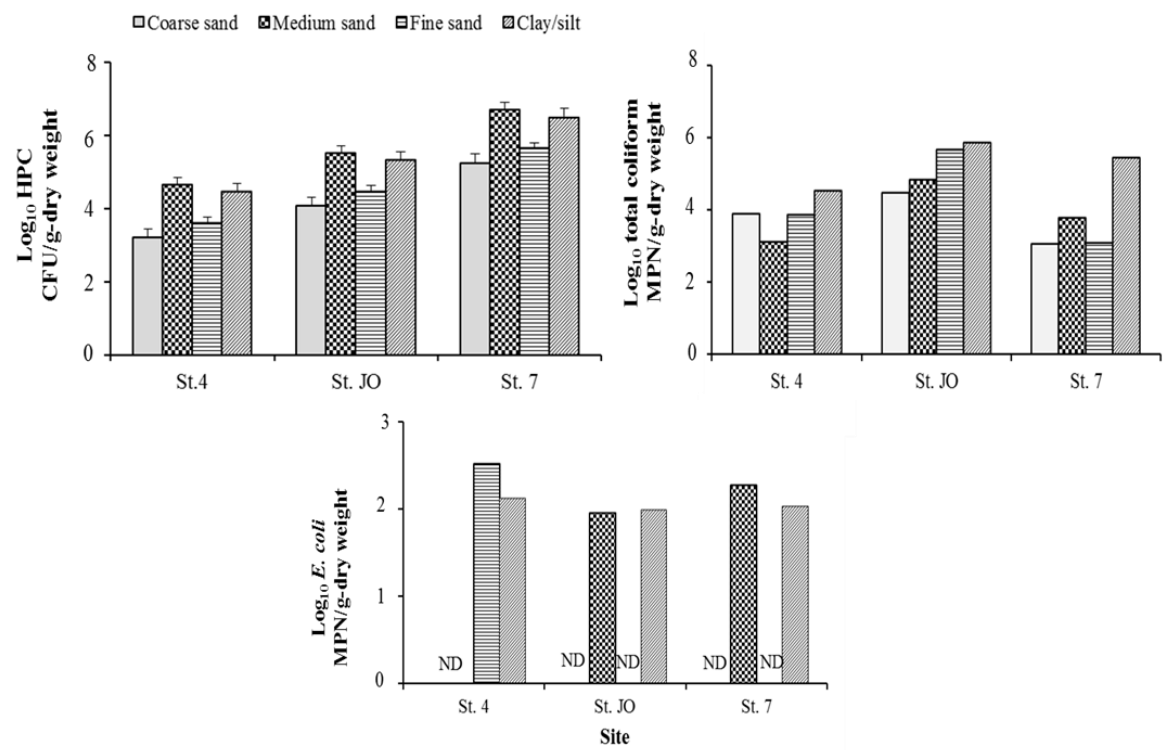

Figure 2. Concentrations of fecal bacterial indicators based on particle fractions in sediment

\subsection{Distribution of fecal indicator bacteria in sediment}

Distributions of fecal indicator bacteria (F-RNA Phages, E. coli, TC, HPC) in sediment along the open channel and drainage channel receiving Johkasou are displayed in Fig. 3. The microbial distributions were measured during winter (January 28 $8^{\text {th }}, 2013$ ), spring (June $11^{\text {th }}, 2014$ ), and autumn (December $9^{\text {th }}, 2014$ ) with the significant difference in flow rate. Flow rate in the autumn season was the highest compared to other seasons.
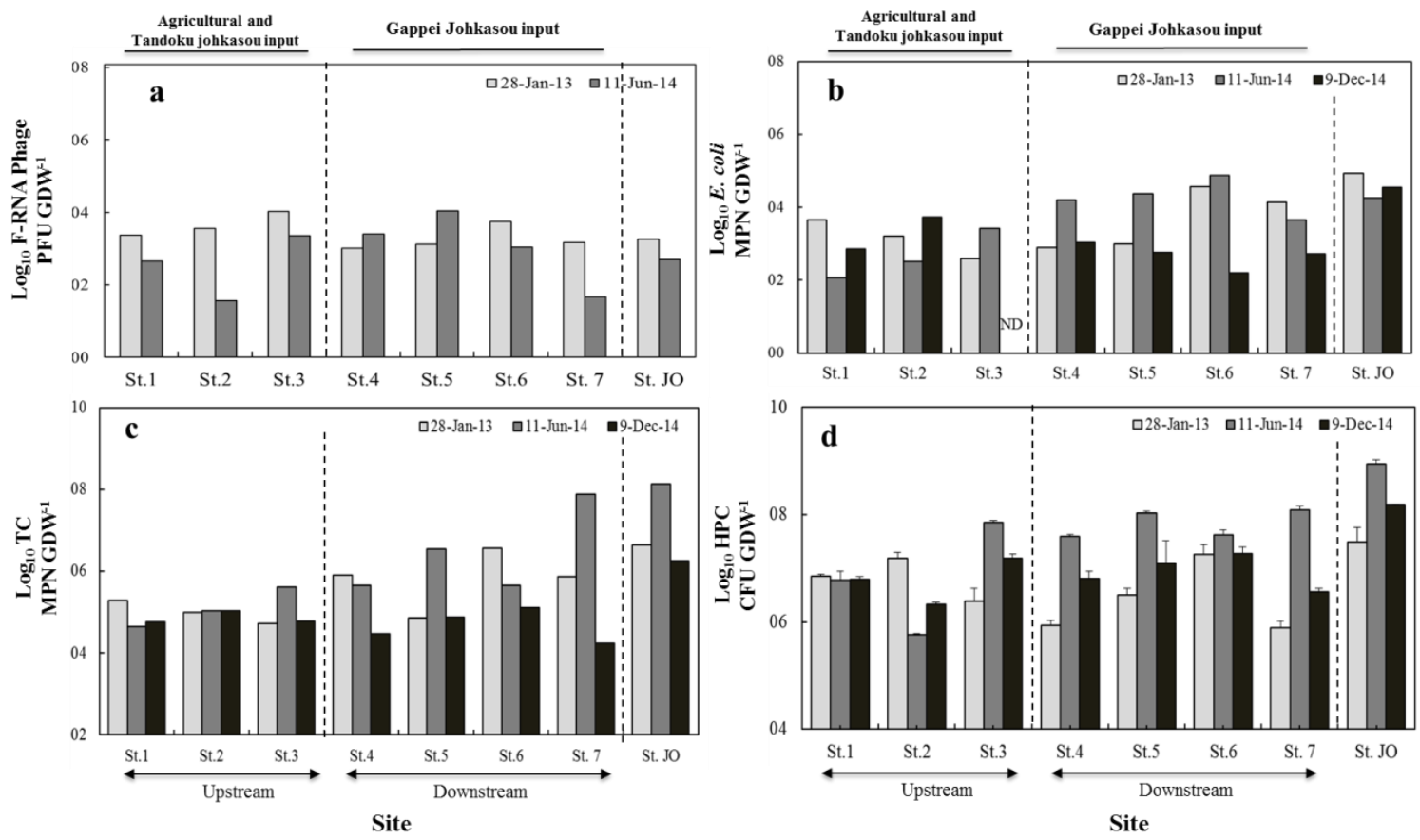

Figure 3. Distribution of F-RNA Phages, E. coli, total coliform and HPC along open channel and drainage channel receiving Johkasou effluent 
Statistically significant differences of fecal bacteria in the sediment among the sites in the open channels were not observed (Fig. 3). The mean contents of F-RNA Phage, HPC, TC, and E. coli in the Johkasou drainage channel were $2.1 \times 10^{3} \mathrm{PFU} / \mathrm{g} 3.5 \times 10^{8} \mathrm{CFU} / \mathrm{g}, 4.8 \times 10^{7} \mathrm{MPN} / \mathrm{g}$, and $4.6 \times 10^{4}$ $\mathrm{MPN} / \mathrm{g}$, respectively. These contents were higher than those parameters in the open channels exclude concentration of F-RNA phage. This indicates that the Johkasou effluent is as the main point source of fecal bacteria particularly in sediment and due to low flow rate effects the fecal bacteria that associated with organic carbon settled down onto the bottom. However, the content of F-RNA phage was higher at St. 3 and St. 5 compared to other sites along the open channel. The effluent of Tandoku Johkasou might be the major reason increasing the F-RNA phage at these sites since Tandoku Johkasou only treats the black water and gray water is discharged into the open channel.

The contents of fecal indicator bacteria along the open channel were different between upstream and downstream area. The content of fecal indicator bacteria was relatively higher in the downstream than in the upstream, which the quantity of domestic wastewater input might affect the water and sediment quality in that area. Continuous effluent discharged from Johkasou into the open channel can be a primary source of contamination that change the water and sediment quality (Jamieson., 2005a). By high the organic content in sediment of Johkasou drainage channel rather than other open channel sampling sites, this could be a source for bacteria to grow and survive in this channel.

Distributions of HPC, TC, and E. coli in sediment fluctuated in seasons along the open channels. The content of microbial indicator was relatively higher during spring compared to winter and autumn. A high flowrate during spring $(74 \mathrm{~L} / \mathrm{min})$ is predicted to carry settleable particles associated with other contaminants including bacteria to the downstream area particularly at St.7 that received water from not only from open channels but also water from paddy field area and another residential area. Many studies reported that high flow event is an important role to carry microbial associated settleable particles and resuspended downstream receiving water. Bacterial indicator organisms exhibited relatively same behavior, with an average of $20-30 \%$ of organisms associated with the particles in dry weather and $30-55 \%$ in storm weather (Characklis et al., 2005). This higher removal of particles-associated microbes relative to the total microbial concentration suggests that sedimentation may be an important role on microbial removal mechanism in the sediment. 
3.3. Relations between microbial indicators and sediment contents.
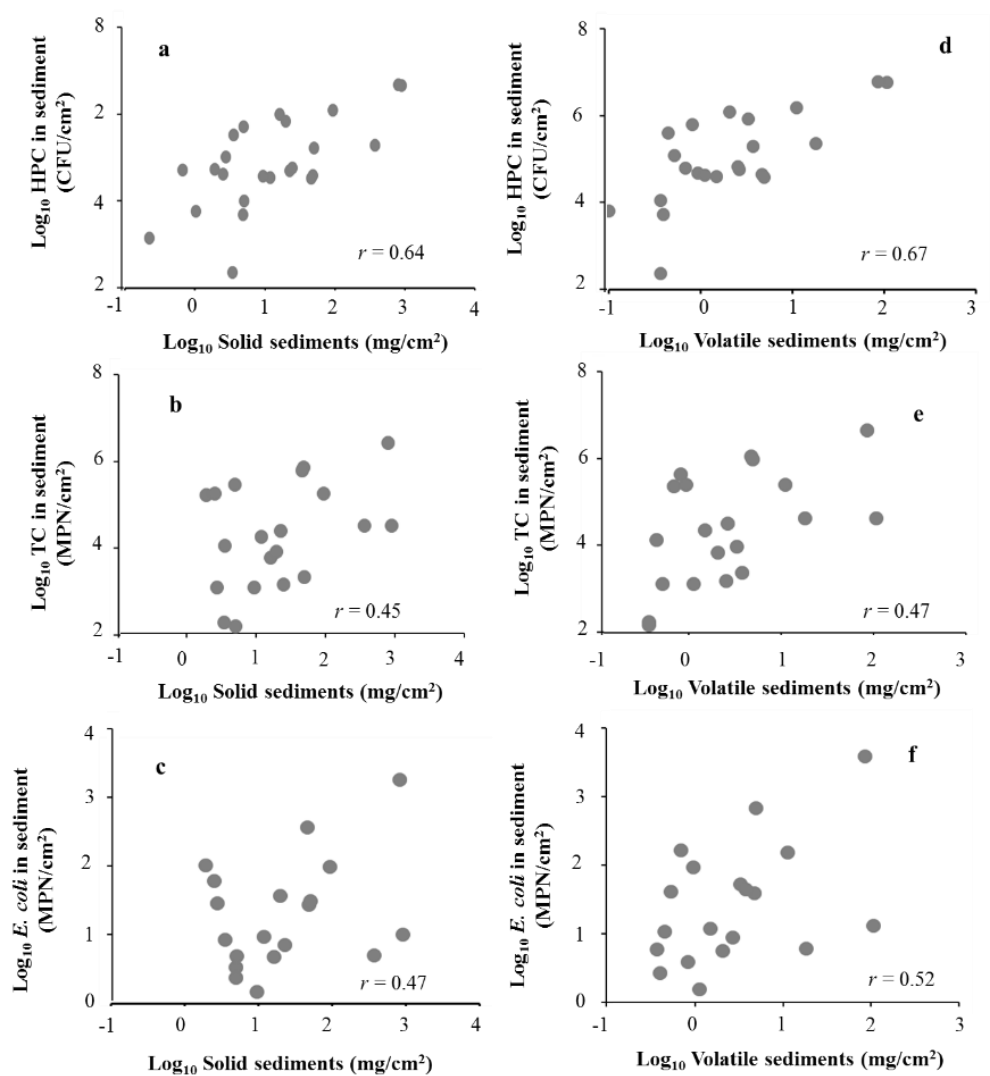

Figure 4. Relationships of sediment microbes for a) HPC, b) TC, and c) E. coli with solids sediments; and d) HPC, e) TC, and f) E. coli with volatile sediments in the open channels receiving Johkasou effluent.

Correlations of microbial indicators and sediment contents were evaluated to identify the behavior of microbes associated sediment particle. The relations between fecal indicator (HPC, TC, and $E$. coli) with sediment particles related to solid sediments and volatile sediments in the open channels receiving Johkasou effluent are displayed in Fig. 4. HPC densities were strongly correlated to solid sediments and volatile sediments ( $r=0.64$ and $r=0.67$, respectively). While, the fecal indicators, TC and E. coli, were moderately correlated with solid sediments $(r=0.45$ and $r=0.47$, respectively) and volatile sediments $(r=0.47$ and $r=0.52)$, respectively. These positive correlations indicate that the microbial indicators associated with sediment particles could be a carrier, especially for volatile sediments as a part of fine particles that export the microbes to the downstream water network. Another study noted that sediment particles of around $20-30 \%$ associated to bacterial indicator organisms during dry weather (Characklis et al., 2005). Furthermore sediment analysis is required to reveal the behavior microbial indicators associated particles sediments that might be a key role on microbial sedimentation during storm events. 


\subsection{Principal component analysis}

In order to obtain important information from the data, PCA analysis was further conducted on the data of distributions fecal indicator bacteria in sediment excluded for F-RNA phage because it was insufficient data. The PCA results were retained the sediment quality into three principal components (PCs) that explained $70.9 \%$ of total variance from the data set (Fig. 5). The three factors are related to the FIB contents, settleable particles, and sediment quantity.
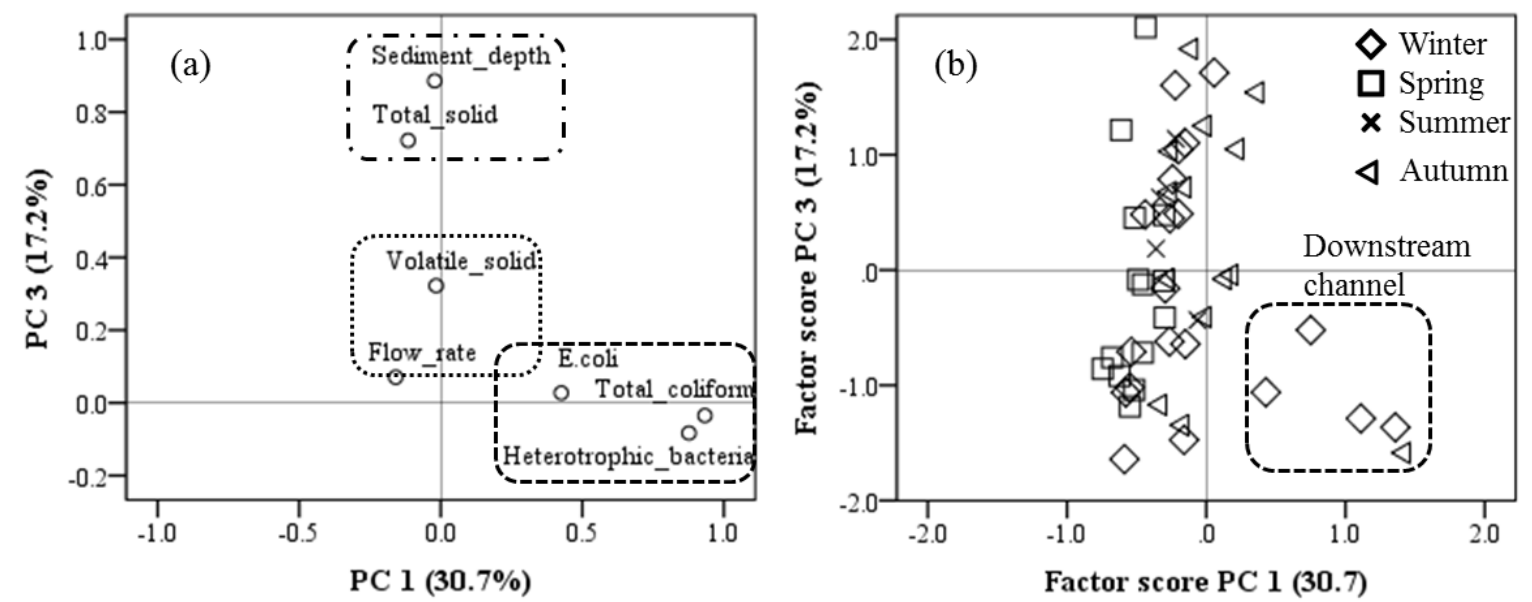

Figure 5 The results of PCA in bi-dimensional plots for scores of seven variables in sediment (a) and factor scores of sites in seasons (b) between FIB contents (PC 1) and sediment quantity (PC 3).

The PC indicated the contents of FIB contrasts with total solid and sediment depth. This showed the content of FIB in the sediment may be affected by the weight of total solid and sediment depth (5a). Thicker of sediment contains high organic contain inside, however, it is less microbial survive in it. The distribution of FIB in sediments of open channels was not significantly different in seasons, although some fluctuations of FIB content could be found in the downstream excluding winter (Fig. $5 b$ ). These fluctuations may be caused by the settleable-particles associated with bacteria and then by low flow rate affected the settleable-particles easily settled down during winter season. Then it increases their concentration in the downstream channel after receiving Johkasou effluent.

\section{CONCLUSION}

Distribution of microbial indicators in sediments of the open channels and the Johkasou drainage channel was evaluated during three different of weathers. The contents of F-RNA phages, HPC, TC, and E. coli in sediment along open channels were recorded at high levels and the sediment of 
Johkasou drainage channel was the highest microbial contents among to the sampling sites in open channels. High contents of E. coli in sediment may reflect the concentrations of E. coli in overlying water and might be the source of the microbes in the downstream area. TC and E. coli contents downstream exhibited increasing trends during spring, which affected by increasing flow rate that can carry the fine particles associated microbes. Positive correlations of most microbial indicators with solid sediments and volatile sediments could suggest the essential of sediments as the carrier to transport sediment particles associated microbes to downstream receiving waters. Furthermore, the results of this study are required further study on microbial removal mechanism in sediments during storm weather.

\section{REFERENCE}

Ahmed, A. U., and D. L. Sorensen. (1995). Kinetics of pathogen destruction during storage of dewatered biosolids. Water Environ Res 67, 143-150.

APHA-AWWA-WEF. (2005). Standard methods for the examination of water and wastewater, 21st ed. APHA, New York, USA.

Ashley, Richard M, Maria Viklander, Jonathan Mattsson, and Annelie Hedstr. (2015). "Impacts and Managerial Implications for Sewer Systems due to Recent Changes to Inputs in Domestic Wastewater E A Review” 161: 188-97. doi:10.1016/j.jenvman.2015.06.043.

Brontowiyono, W., Kasam., Lupianto, R., Agustina., I. (2013). "Strategi Penurunan Pencemaran Limbah Domestik di Sungai Code DIY”. Jurnal Sains dan Teknik Lingkungan, 5(1), pp. 2085-1227. DOI: http://dx.doi.org/10.20885/jstl.vol5.iss1. art5. [Indonesian].

Characklis, G. W., Dilts, M. J., Simmons, O. D., Likirdopulos, C. A., Krometis, L. A. H., \& Sobsey, M. D. (2005). Microbial partitioning to settleable particles in stormwater. Water Research, 39(9), 1773-1782.

Davies, C. M., Long, J. A. H., Donald, M., \& Ashbolt, N. J. (1995). Survival of Fecal Microorganisms in Marine and Fresh-Water Sediments. Applied and Environmental Microbiology, 61(5), 1888-1896.

Griffin, D. W., Gibson III, C.J., Lipp, E.K., Riley, K., Poul, J.H., \& Rose, J.B. (1999). Detection of viral pathogens by reverse transcriptise PCR and of micriobial indicators by standard methods in the canals of Florida Keys. Applied and Environmental Microbiology, 65, 4118-4125.

Indah, S., Li, F., Tanioka, K. Hirooka, K., Yamada, T., (2011). Adsorption Capacity of Bacteriophage $\mathrm{Q} \beta$ onto Activated Carbons. Japan Water Work Association 67, 
III_715-III_723.

Jamieson, R. C., Gordon, R. J., Tattrie, S. C., \& Stratton, G. W. (2003). Sources and persistence of fecal coliform bacteria in a rural watershed. Water Quality Research Journal of Canada, $38(1), 33-47$.

Jamieson, R., Gordon, R., Joy, D., \& Lee, H. (2004). Assessing microbial pollution of rural surface waters - A review of current watershed scale modeling approaches. Agricultural Water Management, 70(1), 1-17.

Jamieson, R. C., Joy, D. M., Lee, H., Kostaschuk, R., \& Gordon, R. J. (2005a). Resuspension of sediment-associated Escherichia coli in a natural stream. Journal of Environmental Quality, 34(2), 581-589.

Jamieson, R., Joy, D. M., Lee, H., Kostaschuk, R., \& Gordon, R. (2005b). Transport and deposition of sediment-associated Escherichia coli in natural streams. Water Research, 39(12), 2665-2675.

Kapoor, Vikram, Tarja Pitkänen, Hodon Ryu, Michael Elk, David Wendell, and Jorge W. Santo Domingo. (2015). "Distribution of Human-Specific Bacteroidales and Fecal Indicator Bacteria in an Urban Watershed Impacted by Sewage Pollution, Determined Using RNAand DNA-Based Quantitative PCR Assays.” Applied and Environmental Microbiology 81 (1): 91-99. doi:10.1128/AEM.02446-14.

Koirala, S. R., Gentry, R. W., Perfect, E., Schwartz, J. S., \& Sayler, G. S. (2008). Temporal variation and persistence of bacteria in streams. Journal of Environmental Quality, 37(4), 1559-1566.

Panasiuk, Oleksandr, Annelie Hedstr??m, Jiri Marsalek, Richard M. Ashley, and Maria Viklander. (2015). "Contamination of Stormwater by Wastewater: A Review of Detection Methods." Journal of Environmental Management 152: 241-50. doi:10.1016/j.jenvman.2015.01.050.

Rehmann, C. R., \& Soupir, M. L. (2009). Importance of interactions between the water column and the sediment for microbial concentrations in streams. Water Research, 43(18), 4579-4589.

Setiyawan, A.S, Yamada, T, Fajri, J.A, \& Li, F. (2014). Characteristics of fecal indicators in channels of Johkasou systems. Japan of Water and Environmental Technology.

Sowah, R., H. Zhang, D. Radcliffe, E. Bauske, and M. Y. Habteselassie. (2014). "Evaluating the Influence of Septic Systems and Watershed Characteristics on Stream Faecal Pollution in Suburban Watersheds in Georgia, USA.” Journal of Applied Microbiology 117 (5): 15001512. doi:10.1111/jam.12614.

Wihters, P.JA., Jarvie, H.P., \& Stoate, C. (2011). Quantifying the impact of septic tank systems on eutrophication risk in rural headwaters. Environment International, 37 644-653. 